\title{
Prehistoric OCCUPATION AT SAKKarRa Site as EARly Metal Phase Tradition and Neolithic Culture Along the Karama DRAINAGE, WeST SUlAWESI ${ }^{1}$
}

\author{
Suryatman (iD) 1 *, Budianto Hakim ${ }^{1}$, Fakhri ${ }^{(D)}$, Andi Muhammad Saiful ${ }^{1,2}$, Hasliana ${ }^{1}$ \\ ${ }^{1}$ Balai Arkeologi Sulawesi Selatan \\ J1. Pajjaiyyang No. 13, Sudiang Raya, Makassar, 90552, Indonesia \\ ${ }^{2}$ Universitas Gadjah Mada \\ Jurusan Arkeologi, FIB UGM, Bulaksumur, Yogyakarta 55281, Indonesia \\ *suryatman.arkeologi@gmail.com
}

Received: 18/08/2018; revisions: 10/09 - 17/11/2018; accepted: 28/11/2018

Published online: 31/12/2018

\begin{abstract}
The Karama drainage region is a prehistoric occupation site, which contains many archaeological data to uncover the history of the arrival and development of the Austronesian-speakers culture in Sulawesi. They have occupied along the Karama drainage since 3,800 years ago, continue to persist and spread to develop of metal knowledge to other areas, both downstream and inland Sulawesi. The in situ cultural layers found on excavations of 2014 with dating around 172 cal BCE to 55 CE. The aim of the study is described of early metal phase culture in Sakkarra Site based on the latest research data. This study used qualitative methods to analyses of cultural layers based on stratigraphic observations, contexts, and artifact findings from several data of excavation conducted in 2014 , 2016 and 2017. The research result shows there is an indication of older occupation, which is the Neolithic phase, continued unabated into the Early Metal Phase at Sakkarra. However, this period does not last long, before finally entering the stage of intensive occupancy by 2,000 years ago. Neolithic cultural traditions have not disappeared and still inherent in their cultural order when metal knowledge begins to present in Karama Drainage. Cultural continuity is reflected in the maintenance of Neolithic technological traditions such as the manufacture of earthenware pottery and polished stone tools. The cultural layer in Sakkara Site indicates the existence of Austronesian speakers' occupation that continues from the Neolithic phase to the initial metal phase in Karama Drainage. Even they are actively involved in the shipping and trade that had intertwined among the islands in Southeast Asia at that time.
\end{abstract}

Keywords: Karama Drainage; culture; metal phase; Neolithic; tradition; Austronesian

\section{INTRODUCTION}

Karama Drainage is one of the prehistoric occupation areas in Sulawesi which has the potential data to uncover the beginning of the arrival, distribution, and development of Austronesian speakers' culture. The sites were found along Karama drainage, and one of the prehistoric sites is claimed as the oldest in the archipelago (see Figure 1). The site is Minangasipakko, located in Kalumpang inferior area, West Sulawesi with the oldest written date is 3,800 cal BP (Morwood et al., 2007; Simanjuntak, 1994; Simanjuntak, Oktaviana, \& Handini, 2016). The date puts Karama Drainage as an area that might be the starting point for the Austronesian speaker arrival before spreading to several archipelago regions (Simanjuntak, 2015: 28-34).

The presence of red slip pottery characterizes the beginning of Austronesians arrival as an indication of early Neolithic occupation, but the last Neolithic layer was replaced by decorated and plain pottery with a lower combustion temperature than the age that ranges from 3,000 to 2,500 cal BP (Simanjuntak, Intan, \& Mahmud, 2007). Some other findings including adzes, grindstone, fragments of stone bracelets, anvil stones, barkcloth beater stones (batu ike), flakes, chert material, obsidian, and some bone points (Simanjuntak et al., 2008). One interesting finding is the presence of obsidian flakes

${ }^{1}$ Other article related to the latest research on the Sakkarra Site also published on November 2018 at Suryatman, Hakim, \& Fakhri, 2018, entitled: The Sakkarra site: New data on prehistoric occupation from the Metal Phase (2000 BP) along the Karama drainage, West Sulawesi. In S. O'Connor, D. Bulbeck, \& J. Meyer (Eds.), terra australis 48 The Archaeology of Sulawesi Current Research on the Pleistocene to the Historic Period (pp. 207-221). 


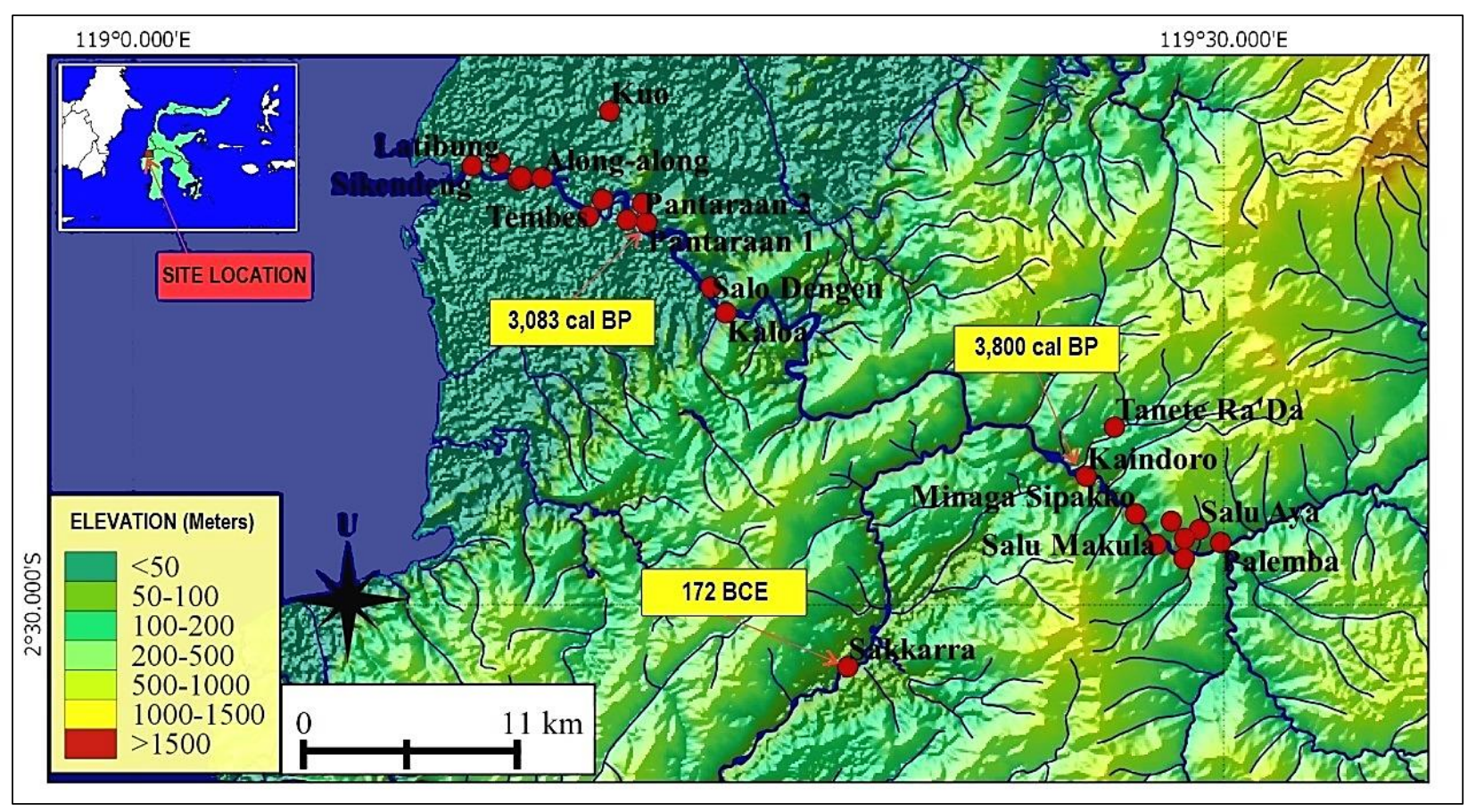

Figure 1. The sites distribution map and date of several sites in previous research along the Karama drainage (Source: Shuttle Radar Topography Mission, 2014; Badan Informasi Geospasial, 2012; Anggraeini, 2012; Fakhri et al., 2015, modified by the Authors)

artifacts of Minangasipakko and Kamassi sites cultural layers (Anggraeni, Simanjuntak, Bellwood, \& Piper, 2014; Hakim, 2014). Obsidian used as a medium of exchange by Southeast Asian and Pacific prehistoric communities as evidence of social interaction among the islands (Spriggs et al., 2011). The absence of obsidian material around Karama Drainage indicates Austronesians involvement in the migration flows at that time. However, recent research has not found a suitable mineral composition between obsidian from Minangasipakko and Kamassi sites and several sources in other parts of Southeast Asia (Reepmeyer et al., 2011). Therefore, an explanation of obsidian origin and function as a medium of exchange in Karama Drainage is still questionable.

For hundreds of years, Austronesian speaker occupation in Karama Drainage continues to spread to several other regions that are not far from Karama drainage. Pantara'an 1 site is one of the sites occupied in the later phase, which lies closer to the coast. The research result indicates that Pantara'an 1 site was once occupied by the date of approximately 3,083 to $2,846 \mathrm{cal}$ BP (Anggraeni, 2012). The chert flakes found in the lowest layer, but obsidian was no more found. The pottery shape indicates the similarities with the pottery from the upper layers of Kamansi and Minangasippakko sites. The occupation phase continues in the site until it enters the metal phase with an indication of metal artifacts and glass beads on the upper layer. This layer has a context related to the jar burial which thought to be less than 2,500 years ago (Anggraeni, 2012; Anggraeni et al., 2014).
Another site that indicates the Austronesian speaker occupation layer in Karama Drainage is Sakkara. This site is the only site located in the south of Karama drainage at the moment, not far from Bonehau River. The site's findings were first reported in 2015 by a survey team funded by The Anthony F. Granucci Fund for Archaeological Research in Indonesia and Timor Leste. The excavation was conducted three months after the discovery and indicated a culture layer that was in situ by date of $172 \mathrm{cal} \mathrm{BCE}$ to $55 \mathrm{CE}$ and $111 \mathrm{cal} \mathrm{BCE}$ to 83 CE (Fakhri, Suryatman, Hakim, \& Sardi, 2015). There were thousands of pottery sherds found in this layers which have related context with metal artifacts, metal slag, glass beads, glass bracelet fragments, barkcloth beater stones, and symmetrical polished stone cog artifacts (Hakim et al., 2014; Suryatman, Hakim, \& Fakhri, 2016). Date and archaeological pieces of evidence indicate the early prehistoric phase and the latest age site in Karama Drainage at this time.

Further research was performed by Balai Arkeologi Sulawesi Selatan in 2016 and 2017 to see a wider horizontal distribution of findings in Sakkarra Site (Hakim et al., 2016; 2017). The research question is what is the occupation culture stage chronology in Sakkarra Site based on the latest research? This paper indicates the excavation data of the last two years and combines the previous excavation data, both stratigraphic and finding distribution data vertically and horizontally. Result and Discussion explain the cultural development in Karama Drainage when the early stages of metal phase presents in the stages of prehistoric Austronesian speakers in Sulawesi. 


\section{MeTHODS}

The used research data is excavation data between 2014, 2016, and 2017 in Sakarra Site. The geographic coordinates are $02^{\circ} 31^{\prime} 42.0^{\prime \prime} \mathrm{S} 119^{\circ} 19^{\prime} 40.1^{\prime \prime} \mathrm{E}$, and the elevation is 84 meters above sea level. Administratively the location is in Bonehau Village, Bonehau District, Mamuju Regency, Sulawesi Barat, Indonesia. Land surface condition on the site was estimated around $80 \%$ already extracted by mining activities in 2012 before the site was found (see Figure 2B). The excavation was conducted by dividing the two sectors, to facilitate data recording due to the site's extensive condition. Sector 1 within a $40 \mathrm{~m}$ to the east of Sector 2. The excavation squares in Sector 1 and 2 used a different datum line. The difference in land surface height between Sector 1 and 2 is $6 \mathrm{~m}$; the soil surface in Sector 1 is lower than Sector 2 (Figure 3). Excavation squares in Sector 1 consisted of T2 S1, B2 S1, B3 S1 in 2014, B1 S2 and B1 S3 in 2016, and T8 S3 in 2017. Excavation in Sector 2 in 2017 was conducted to follow up on information from a landowner about the discovery of jars around the site when digging. (see Figure 2F). The excavation was performed in 2010 for the yard before finally being leased by the mine production for five years. Excavation in Sector 2 consisted of 2 squares, namely TP 1 and TP 2.

Data recording used a 1 x $1 \mathrm{~m}$ grid (square) excavation method, while the deepening used a spit system with a depth interval of 10 on each spit. Spit 1 as the first spit was dug up to $30 \mathrm{~cm}$ below the datum line. The artefactual analysis processed on all excavation squares by classifying the archaeological types. Specifically, for pottery sherds, they were classified according to the sherds shape, surface finish, and body parts thickness. Samples of pottery sherds that had relatively large fractional diameters were reconstructed to determine their shape.

\section{RESUlt AND DISCUSSION}

\section{Stratigraphy and Cultural Layer}

Stratigraphy on Sector 1 of 6 excavation squares consists of four soil layers (see Figure 4). Layer 1 was top surface soil with very fine sand and dark brown (7.5 YR 3/4 dark brown). This layer was mixed with dry leaves, roots, and grass with a thickness of 10 to $20 \mathrm{~cm}$. This layer has a depth of up to $40 \mathrm{~cm}$ from datum line. Layer 2 is yellowish sandy clay (10 YR 4/6 dark yellowish brown). This layer has a thickness of 40 to 70 $\mathrm{cm}$, seen from a depth of 90-100 cm from datum line. Textured layers of clay mixed with charcoal and ashes stick to the middle of Layer 2 were seen in T8 S3 square, but there was no indication of archaeological findings around this layer. Pottery sherds found at the end of Layer 2, before entering Layer 3.

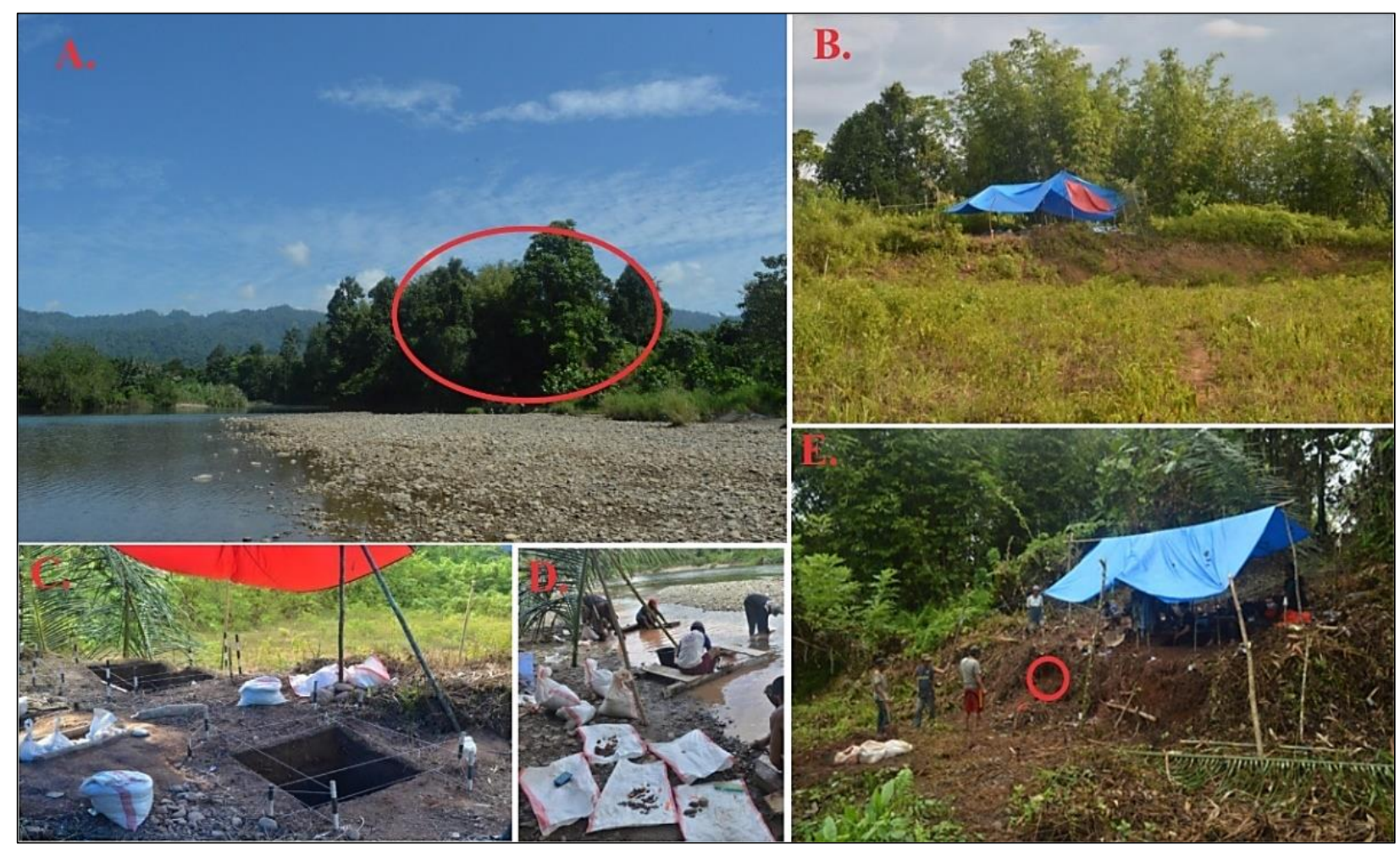

Figure 2. Location and excavation activities in Sakkarra Site photos. Figure 2A The Sakkarra site location on a hillock along the bank of the Bonehau River. Figure 2B indicated the former mining site and the location of excavation squares in sector 1 .

Figure $2 \mathrm{C}$ indicated excavation squares in sector 1 . Figure 2D indicated the activity of wet sieving from the excavation squares in the river bank. Figure 2E indicated finding location of earthenware sherds by local people (red circle) in sector 2 (Source: Balai Arkeologi Sulawesi Selatan, 2014; 2016; 2017) 


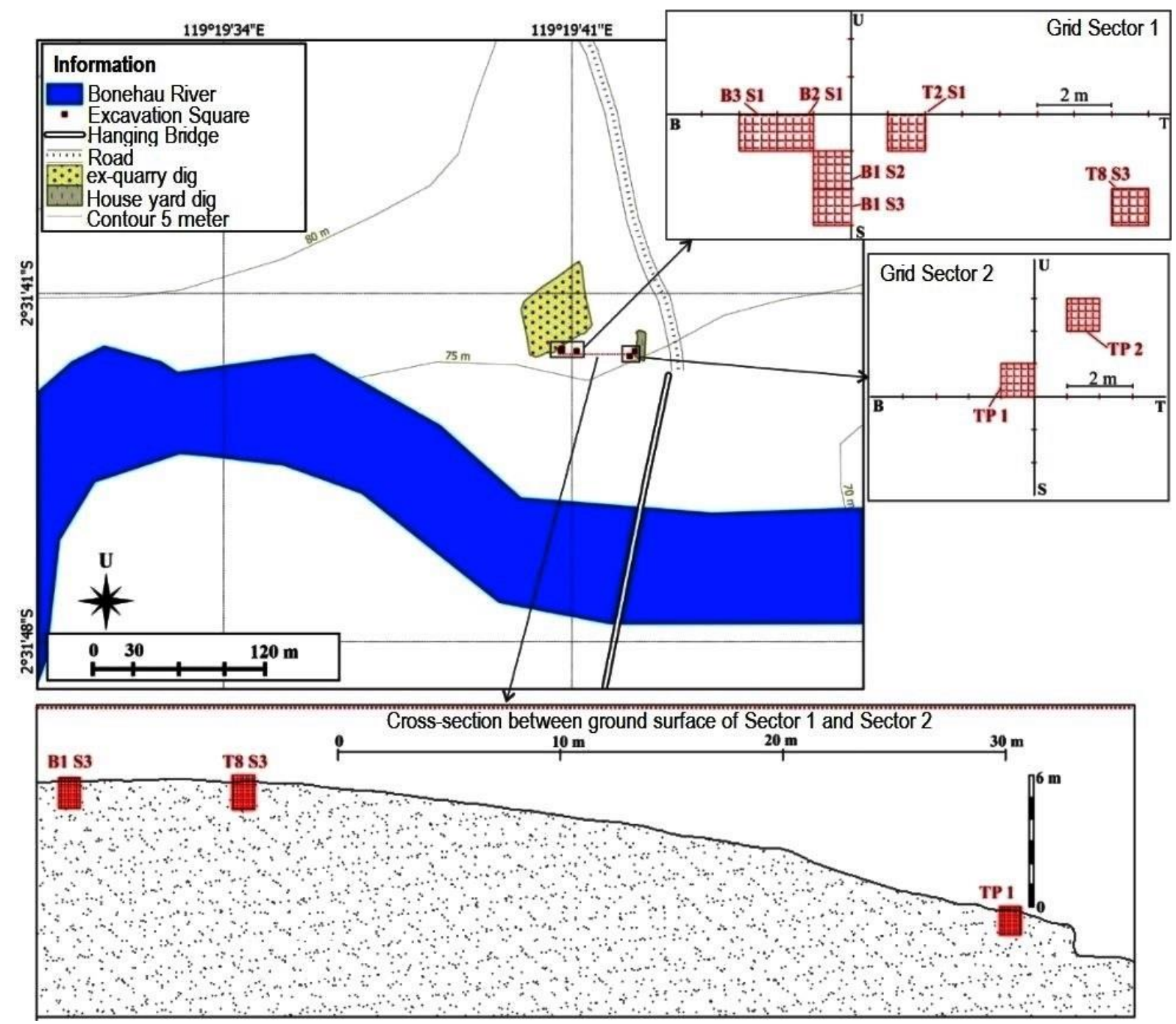

Figure 3. The excavation squares location and grid floor plan in Sakkarra (Source: Balai Arkeologi Sulawesi Selatan, 2017)

Layer 3 was dark brown silt (2.5 Y $3 / 3$ dark olive brown). This layer indicates the thickness of 10 to $80 \mathrm{~cm}$ but looks thinner on T8 S3 square. The findings of pottery sherds were very dense at this layer. These findings mixed into one with polished stones and chunks of volcanic material. The dating data of Layer 3 from T2 S1 square depth of $80-90 \mathrm{~cm}$ from datum line (spit 9) showed $111 \mathrm{cal}$ BCE to $83 \mathrm{CE}$ and depth of $90-100 \mathrm{~cm}$ from datum line (spit 10) showed $172 \mathrm{cal}$ BCE to $55 \mathrm{CE}$ (Fakhri et al., 2015).

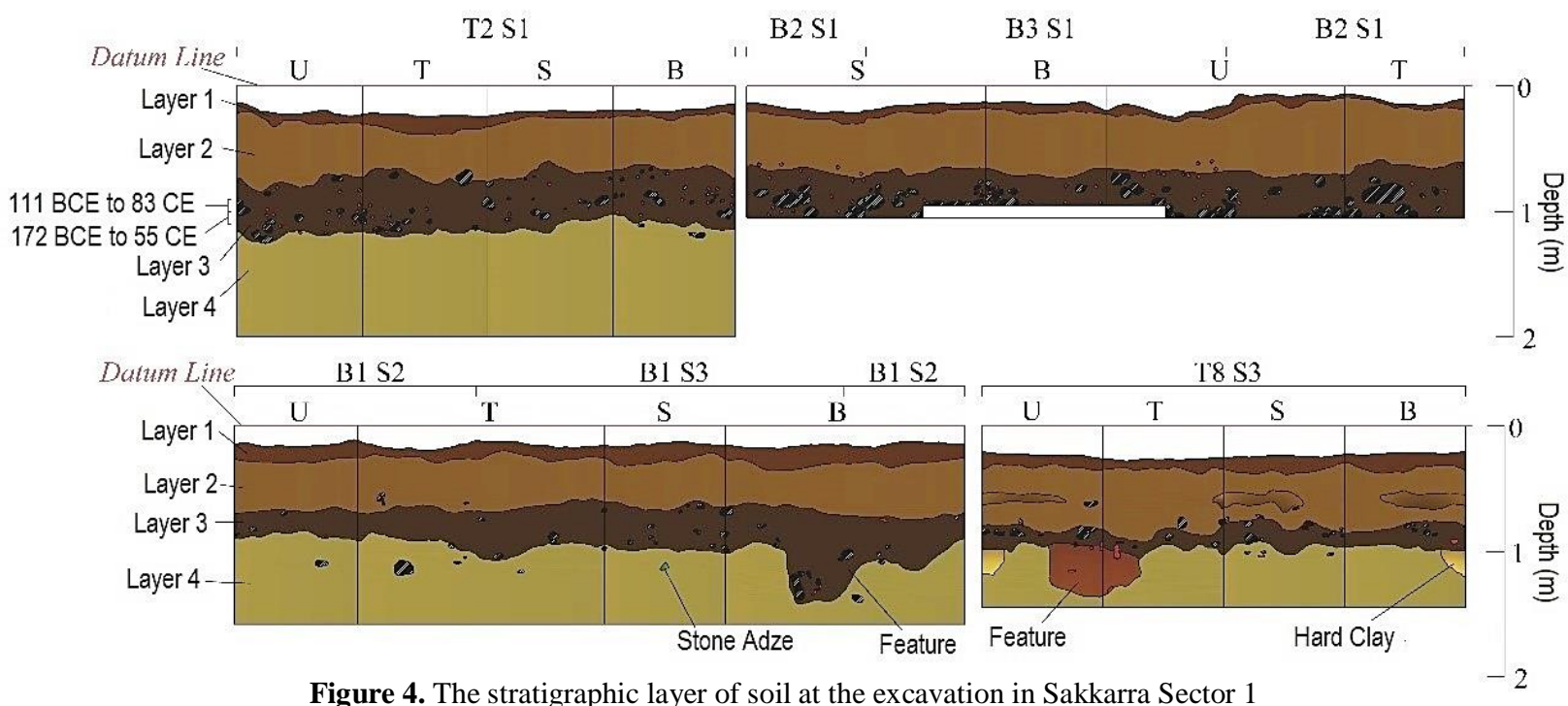

Figure 4. The stratigraphic layer of soil at the excavation in Sakkarra Sector 1 


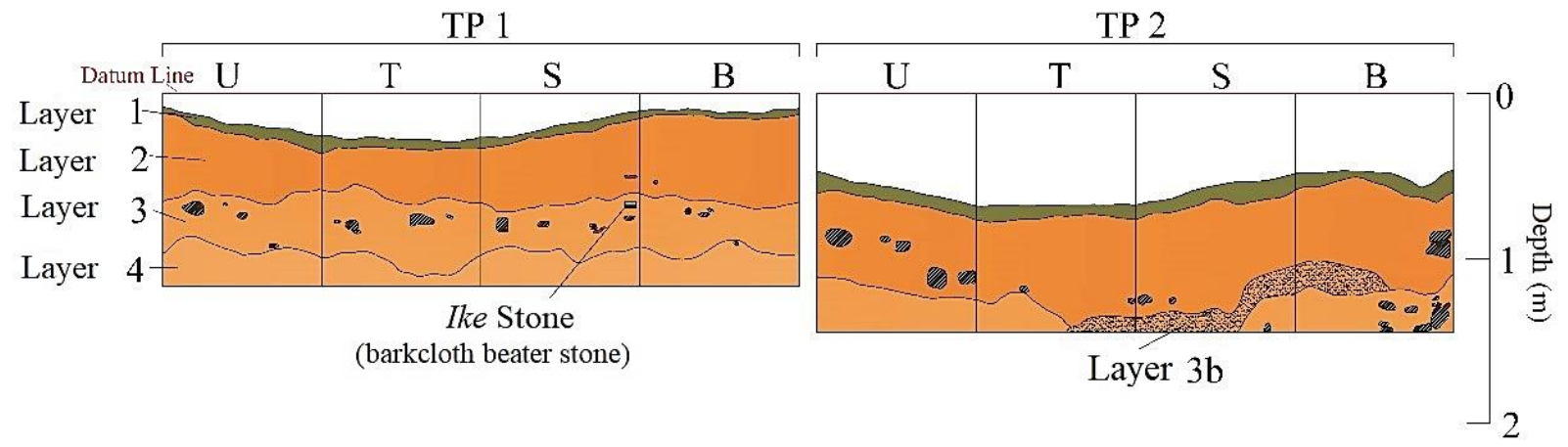

Figure 5. Stratigraphic soil layer of two excavation squares at Sector 2 Sakkarra Site

(Source: Balai Arkeologi Sulawesi Selatan, 2017)

The feature layer was also seen on the west side wall of B1 S2 square and the north side wall and east side of T8 S3 square. The soil color in T8 S3 square feature layer of the T8 S3 square is somewhat different from the color of layer 3. The soil in the reddish brown feature layer (2.5 Y 6/8 reddish brown) was mixed with charcoal concentration and several large pottery sherds but not vessel form. Not far from this feature was also seen hard clay soil layer, might be burned land former, the feature layer suspected of being excavated from combustion activities.

Layer 4 was yellowish clay soil (clay) (2.5 Y 6/8 olive yellow). This layer was the last visible layer until the end of the spit surface. Archeological indications not found in T2 S1 and B1 S2 squares. However, in B1 S3 and T8 S3 square, there were some pottery sherds, especially red slip pottery on the upper surface of Layer 4. A polished adze also found attached to Layer 4 of B1 S3 square (Figure 4). Cultural layer indicates in Layer 4 but very thin. Therefore, this layer may not be occupied for a long time.

Excavation in Sector 2 indicates the soil layer stratigraphy which tends to be different from Sector 1 . The layer was dominated by clay texture, and each layer can only be distinguished from the soil color and findings concentration (see Figure 5). The soil surface in TP 2 square was lower than TP 1 square. Stratigraphy in Sector 2 consists of four soil layers. Layer 1 was brownish sandy silt (7.5 YR 5/4 brown). Layer 1 mixes with grass and roots with a thickness of 10 to $20 \mathrm{~cm}$. Layer 2 was yellowish red clay (5 YR 5/8 yellowish red). This layer indicates a thickness of 30 to $60 \mathrm{~cm}$. Pottery sherds in TP 1 square found at the end of Layer 2.

Layer 3 was yellowish clay (5 YR 5/8 yellowish red). Pottery sherds were found relative densely associated with cobbles of volcanic stone. Barkcloth beater stone is found attached to this layer on the corner of between the south wall and the west wall (see Figure 5). Layer 3

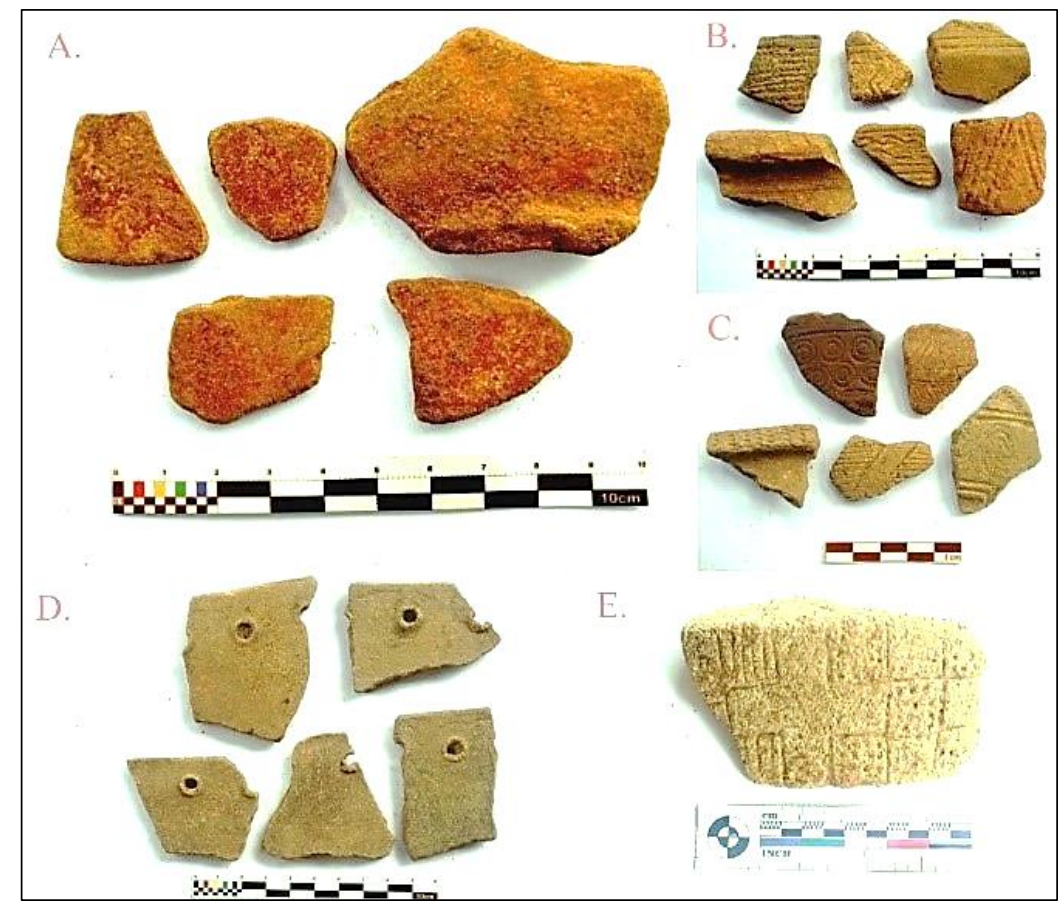

Figure 6. Red slip and decorated earthenware pottery sherds from Sakkarra Site. Red slip pottery sherds from S3 T8 square spit 9(6A). Decorated pottery sherds from S3 T8 spit 7 (6B and 6C), B1 S2 square (6D) and B3 S1 spit 6 (6E)

(Source: Balai Arkeologi Sulawesi Selatan, 2014; 2016; 2017; Fakhri et al., 2015) 
indicates a thickness of 50 to $70 \mathrm{~cm}$. Layer $3 \mathrm{~b}$ appears in TP 2 square of the west side, south side, and east side. Layer 3 was clay soil mixed with coarse sand and gravel with a thickness of 10 to $20 \mathrm{~cm}$. Several pottery sherds were still found in this layer. Layer 4 was reddish clay (5 YR 4/6 yellowish red). This layer only visible at the end of excavation at TP 1 square. Stone and pottery sherds no more found in this layer.

The stratigraphic data above indicates that the cultural layer with intensive occupation found at Layer 3, both in Sector 1 and Sector 2. Solid pottery sherds were found to be associated with crustaceans and stone lumps, metal artifacts, metal slag, glass artifacts, and stone artifacts (see Table 1). Indications of older occupancy were also found below Layer 3, but only in Sector 1 . Some pottery sherds, mainly red slips, and a stone adze were found on the upper Layer 4. This layer indicated a Neolithic culture occupancy (pre-metal phase) but may not last for a long time.

\section{Pottery}

The total quantity of earthenware from the excavation amounted to 26,860 sherds. These were predominantly body sherds $87.76 \%(\mathrm{n}=23,572)$, supplemented by rim sherds $10.12 \%(\mathrm{n}=2718)$. Lip section sherds $(n=7)$, spout $(n=1)$, base $(n=21)$, foot $(n=24)$, carination $(n=176)$, ear $(n=1)$, neck $(n=2)$, handle $(n=3)$, cover $(n=23)$, and ear $(n=5)$ each under $1 \%$. Pottery sherds are not identified as suspected as nonvessel pottery with $1.14 \%(n=307)$.

Plain category of pottery sherds dominates with a percentage of $97.58 \%(n=26,211)$. Decorated pottery sherds $(n=324)$ and red slips $(n=325)$ is only $1.21 \%$ of each. The red slip pottery sherds begin to appear dominant from spit 8 to spit $12(90-140 \mathrm{~cm}$ from the datum point) in B1 S2 square $(\mathrm{n}=94), \mathrm{B} 1 \mathrm{~S} 3(\mathrm{n}=105)$, T2 S1 ( $=9)$, and T8 S3 (117) (Figures 6A and 7). The dominant red slip pottery sherds were found at Layer 4 in Sector 1, which were thought to be a layer of pre-metal

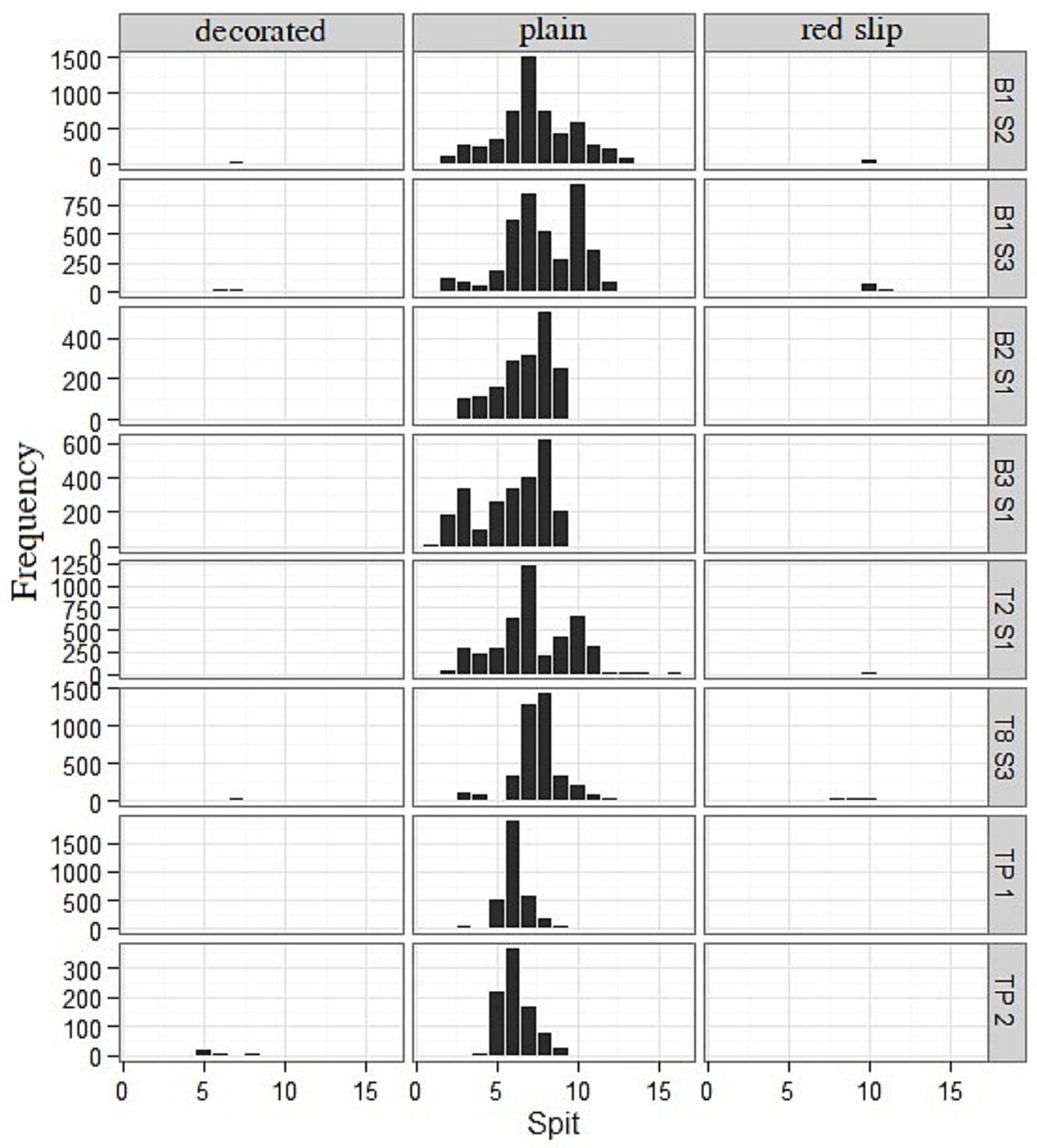

Figure 7. Pottery sherds frequency of each excavation square at Sakkarra comparison (Source: Balai Arkeologi Sulawesi Selatan, 2014; 2016; 2017; Fakhri et al., 2015) 


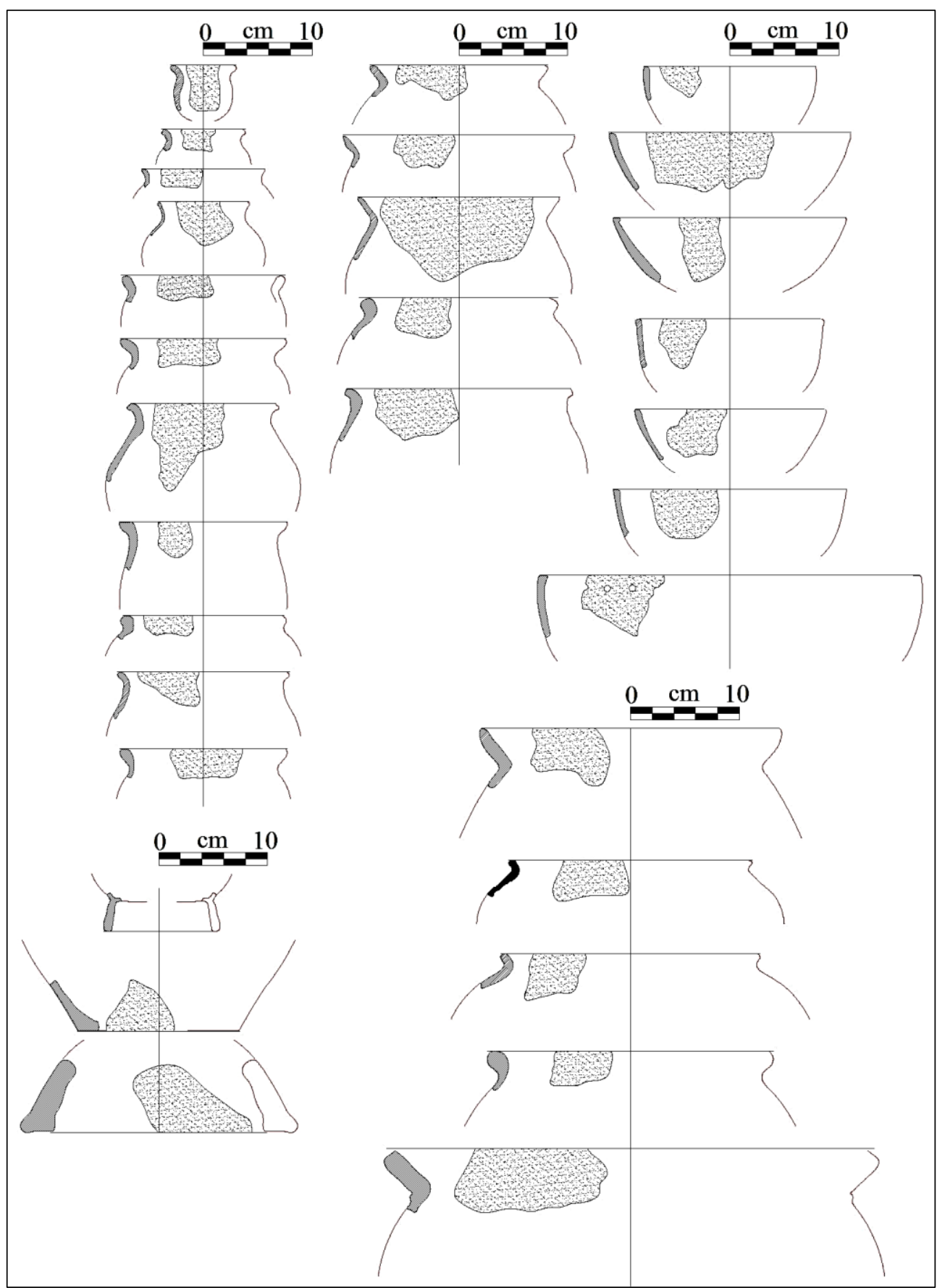

Figure 8. Reconstruction of the earthenware vessel forms at the Sakkarra site based on several rims, base, and foot pottery sherds in Sakkara Layer 3

(Source: Balai Arkeologi Sulawesi Selatan, 2017)

phase over 2,000 years ago. There are no red slip pottery sherds both in Sector 2 excavation squares until the end of excavation. Based on the initial analysis, the utilizing possibility of initial occupation activity was not conducted around Sector 2.

The dominant decorated pottery sherds were found from spit 4 to spit 9 (depth of 50-100 $\mathrm{cm}$ from datum point) on all excavation boxes. The motifs are varied, including punctate holes, parallel circles, diagonal lines, a combination of parallel and curvilinear lines, as well as a combination of lines, squares, and punctate stamping (see Figure 6). Some decorated pottery motifs such as circles and punctate stamping (see 6C and 6B) are similar to the decorated pottery motifs from the older cultural layers in the region. Decorated motifs of punctate stamping and circles are middle Neolithic cultural layer markers (3,200 to 2,500 cal BP) in Karama Drainage, particularly on Kamansi and Minangasipakko sites (Anggraeni, 2012; Anggraeni et al., 2014). However, the presence at Sakkarra indicates that the ornamental motif technology continues to enter the metal phase, even though the implementation intensity is decreasing.

The result of pottery sherds reconstruction of the vessel forms from Layer 3 indicates the most varied shapes and sizes (see Figure 8). A covering vessel consists of pots, cooking pots (periuk), and large open jars (tempayan) 
with rim diameter between $3 \mathrm{~cm}$ to $23 \mathrm{~cm}$. An opened vessel is bowl with rim diameter between 8 to $18 \mathrm{~cm}$. The shape is generally intended for household activities.

\section{Glass Artifacts}

Glass artifacts found in pieces of bracelets and beads fragments. These artifacts found in all squares, except TP 2 , and only distributed in Layer 3. Bracelets fragment are 3 semicircular, consists of green, clear white, and dark blue. The color of all bracelet fragments was more transparent than glass beads. The total number of glass beads from excavation amount to 35 pieces. Glass beads are generally round in shape consists of red, black, yellow, green, dark blue, sky blue, and brown. The found of glass beads tend to be relatively small with an average weight of 0.2 grams, ranging from 0.04 to 0.51 grams.

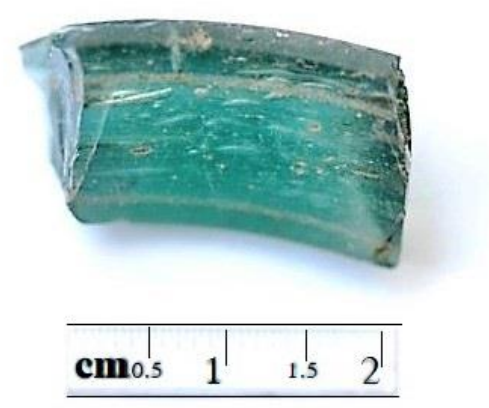

Figure 9. Glass bracelet fragments from spit 6 B3 S1 square (Source: Balai Arkeologi Sulawesi Selatan, 2014)

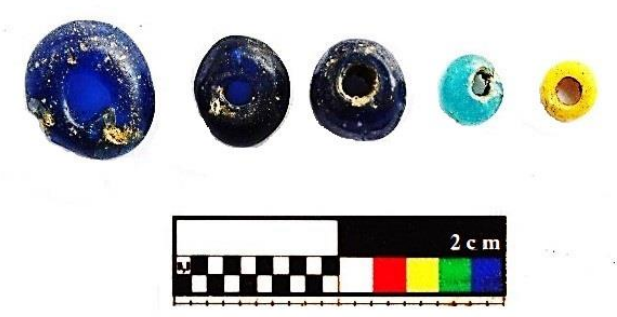

Figure 10. Glass beads from spit 4, 6, and 8 B1 S2 square (Source: Balai Arkeologi Sulawesi Selatan, 2016)

These artifacts identified as Indo-Pacific beads which are commonly found in some prehistoric sites, especially burial sites in the Southeast Asia region. Based on the distribution, manufacturing technique, color, and materials, these beads are also known as Indo-Pacific Monochrome Drawn Glass Beads (Nasruddin, 2016).

\section{Slag and Metal Artifacts}

Iron slag overall weight of all boxes is 1,311 grams. The dominant iron slag found in Layer 3, but several slags also found in Layer 2 of T2 S1 and T8 S3 squares.
The most massive iron slag as large an adult's hand size of 428 grams found in spit 9 of T2 S1 box (Figure 11A).

Found metal artifacts from excavation squares were 4 pieces. One of them is shaped like a fish hook, but found in Layer 2. The artifact is doubtful from the prehistoric cultural layer because the finding position is in Layer 2 and far enough to Layer 3 (Figure 11B). Three other artifacts found in Layer 3, spit 5, and 6 squares B1 S3 and spit 7 squares B1 S2. The three artifacts have a flat elongated shape with very thick slag. The weight of metal artifacts in B1 S3 square from spit 5 is 15 grams and spit 6 is 13.94 grams while in B1 S2 square, spit 7 is 30.78 grams.

The presence of iron slag associated with metal artifacts in Layer 3 is a strong indication of metal technology knowledge possessed by Sakkarra occupants. Metal technology knowledge, mainly iron, has spread rapidly since 2,000 years ago in Southeast Asia and can be made easily by a small community when there is an awareness of the potential and easier materials availability (Bellwood, 2007).
A.
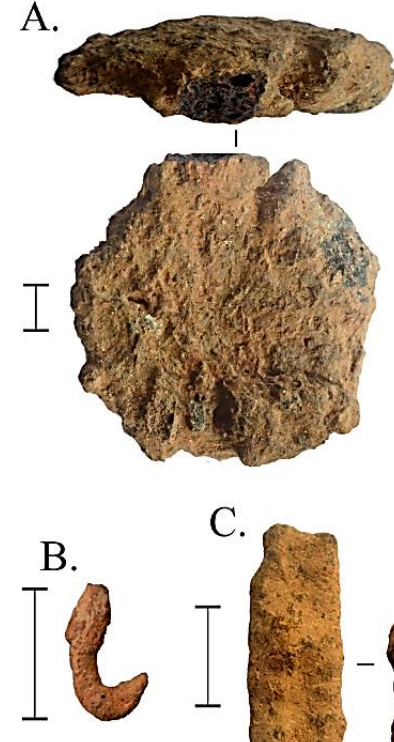
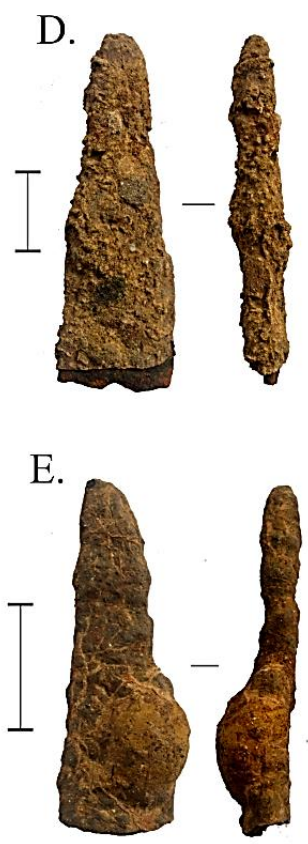

Figure 11. Iron slag and artifacts from Sakkara excavation. Iron slag from spit 9 T2 S1 square (11A), metal artifact hookshaped from spit 3 B3 S1 square (111B), a metal artifact from spit 5 B1 S3 square (11C), spit 7 B1 S2 square (1D) spit 6 B1 S3 square (11E). A scale of $2 \mathrm{~cm}$

(Source: Balai Arkeologi Sulawesi Selatan, 2014, 2016, Fakhri et al., 2015)

\section{Stone Artifacts}

Stone artifacts identified from all excavation squares by 57 artifacts. The artifact consists of several categories, i.e. 4 pieces of polished adzes, 21 pieces of polished adzes fragments, 1 piece of cog stone, 2 pieces of barkcloth beater stones, 1 piece of chiseled stone, 12 pieces of support stones, 7 pieces of grindstones, 1 
grindstone fragments, 1 stone adze, 3 chert flakes, and 1 anvil stone (see Figure 12). A stone adze found attached on the south side wall of Layer 4, square B1 S3 (Figure $12 \mathrm{~B}$ ), associated with the several red slip pottery sherds. It strongly suspected that stone adze comes from the Neolithic occupation phase at Sakkarra Site. However, most other stone artifacts were still found in Layer 3.
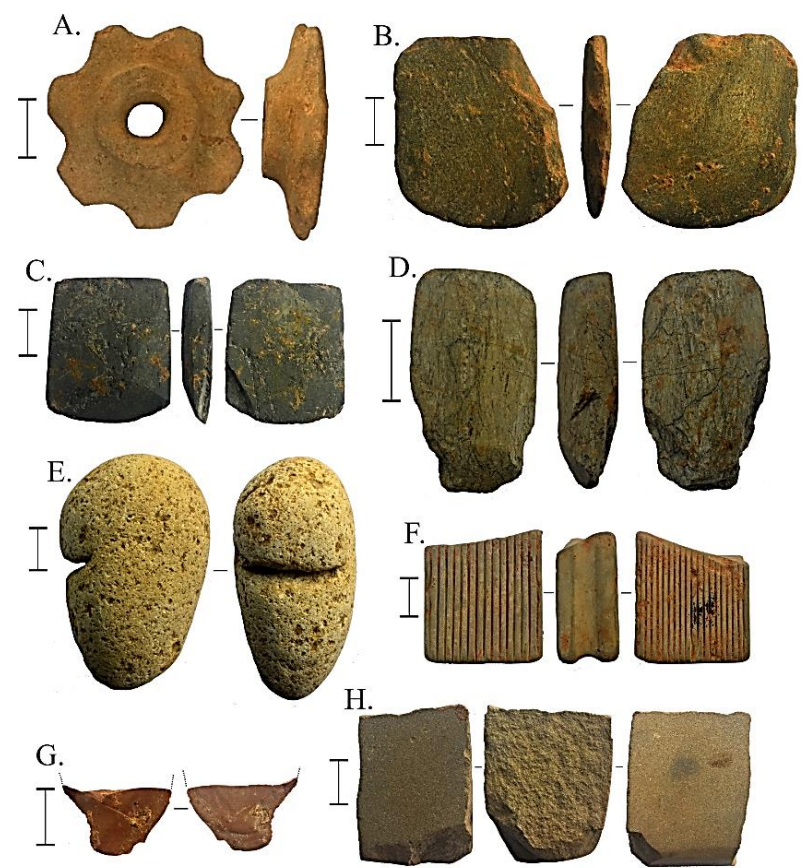

Figure 12. Stone artifacts from Sakkarra excavations. Cog stone artifacts from square T2 S1 spit 11 (12A). Stone adze attached on the wall of Layer 4 southern side of square B1 S3 spit 10 (12B). Polished adzes from spit 10 in B1 S3 square (12C) and spit 9 in T8 S3 square (12D). Support stone with an indication of cutting traces from spit 9 in B1 S2 square (12E). Barkcloth beater stone attached on the south side wall of spit

5 in TP1 square (12F). Chert flakes from spit 10 in T8 S3 square (12G). Whetstone from spit 10 in B1 S2 square $(12 \mathrm{H})$. A scale of $2 \mathrm{~cm}$

(Source: Balai Arkeologi Sulawesi Selatan, 2014, 2016, 2017, Fakhri et al., 2015)

Cog stone artifact has a diameter about $10 \mathrm{~cm}$, from Layer 3 spit 11 in T2 S1 square. The artifact has a circular shape with symmetrical teeth around its perimeter, resembling the shape of a gear used on machine tools (see Figure 12A). In the middle, there is a translucent hole with a diameter of $1.6 \mathrm{~cm}$. The hole also surrounded by a circle that appears on one side only with a diameter of 3-4 cm and a thickness of $0.8 \mathrm{~cm}$. The artifact made with polished volcanic rock, but the symmetrical shape display remarkably adept technology compared to other stone artifacts. This stone artifact first discovered in the Austronesian prehistoric cultural layer in Southeast Asia. Its function is not clear, but it may have been used in smelting metal.

One of the support stone indicates the cutting marks on one side (see Figure 12E). This artifact a volcanic pebble which may have taken from the river around. The very deep pieces (about 1-1.5 cm) and open up (3-4 cm) are the markers of metal tools used to make stone tools.

\section{Discussion}

Recent research data indicates the older occupation layers (Neolithic phase layers), before entering the early metal phase at Sakkarra site. The layer marked by several pottery sherds, especially the red slip pottery sherds, associated with a stone adze below the metal layer. However, the occupation may not last long and does not take advantage of a wider space scale than in the next phase. Date data have not supported the layer, the dating analyses only based on the stratigraphic position and the findings.

Intensive occupancy lasted at around 2,000 BP (172 cal $\mathrm{BCE}$ to $55 \mathrm{CE}$ ) when the practice of metal smelting came to the Karama Drainage. However, Neolithic traditions still persisted. One of them is polished technology in making stone artifacts. Several types of tools, such as adze, continue produced at Sakkarra Site. The development of metallurgy did not lead to the loss of polished stone technology. This technology is even more complicated, as evidenced by the discovery of cog stone artifacts produced with a symmetrical shape pattern. Metal artifacts may also be used as a tool for making more complex stone artifacts.

Besides stone artifact technology, other neolithic traditions are pottery technology, particularly in terms of giving motifs on the pottery surface. One of the typical decorative techniques from the Neolithic phase is the point punctate and circle motifs. This technique still found in Sakkarra site pottery motif, but it is scarce. The dominant decorative motif that has just emerged is parallel translucent holes, commonly seen on the rim of the uncover vessel such as bowl (see Figure 6D). Although decorated pottery still found to the upper layer, it is decidedly less amount compared to plain pottery. Decorated vessel pottery may account intended for certain things.

The presence of glass artifacts, especially IndoPacific glass beads from Sakkarra Site is a strong indication of intensively intertwined social interaction, both between community groups in Karama Drainage, and inter-islands in the Southeast Asian region. Glass beads are one of the most substantial evidence of intense trade relationship between India and Southeast Asia since 200-500 BCE (Bellwood, 2007). However, Austronesian occupancy in Karama Drainage also indicates their involvement in maritime shipping and trade that occurred at that time. Besides glass beads, other evidence has also been reported but not supported by dating and stratigraphic data is Buddhist statue which Amarawati type from Sikendeng Site in 1933 (Simanjuntak et al., 2007) and cornelian glass beads on 
Lattibung Site, Karama drainage downstream (Fakhri et al., 2015) and Tabun Cave Site in Karama drainage upstream (Anggraeni, 2012).

Metal phase cultural layer in Sakkarra Site indicates the existence of Austronesian speakers. Austronesian speakers continue occupied in Karama Drainage from the beginning of their arrival, before finally spreading and occupying other areas in the interior of Sulawesi, such as Timooni Site, Rampi Valley with a date of 1,800 years ago and Lake Matano Region with the date between 2,000 and 1,600 years ago (Yuniawati, 2014).

Table 1. Distribution of the excavated finds in the Sakkara Site

\begin{tabular}{|c|c|c|c|c|c|c|c|c|c|c|c|c|c|c|c|c|c|c|}
\hline 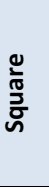 & जे & 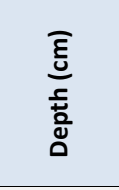 & $\begin{array}{l}\text { Zù } \\
\text { ث̃ } \\
\text { o }\end{array}$ & 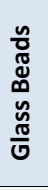 & 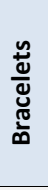 & 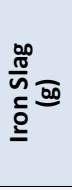 & $\begin{array}{l}\bar{J} \\
\sum \\
\sum\end{array}$ & 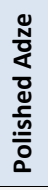 & 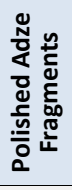 & 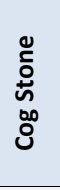 & 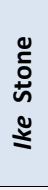 & 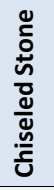 & 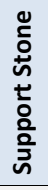 & 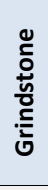 & 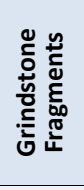 & 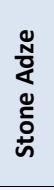 & $\frac{\mathscr{\mathscr { u }}}{\frac{\tilde{\pi}}{\tilde{u}}}$ & 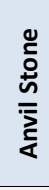 \\
\hline \multirow{18}{*}{$\begin{array}{l}\vec{n} \\
\stackrel{\sim}{F}\end{array}$} & 1 & $0-30$ & & & & & & & & & & & & & & & & \\
\hline & 2 & $30-40$ & 31 & & & 56 & & & & & & & & & & & & \\
\hline & 3 & $40-50$ & 285 & & & & & & & & & & & & & & & \\
\hline & 4 & $50-60$ & 224 & & & & & & & & & & & & & & & \\
\hline & 5 & $60-70$ & 294 & & & & & & & & & & & & & & & \\
\hline & 6 & $70-80$ & 640 & & & 145 & & & & & & & & & & & & \\
\hline & 7 & $80-90$ & 1,218 & 4 & 1 & & & & & & & & & & & & & \\
\hline & 8 & $90-100$ & 197 & 2 & & & & & & & & & & & & & & \\
\hline & 9 & $100-110$ & 417 & 1 & & 428 & & & & & & & & & & & & \\
\hline & 10 & $110-120$ & 656 & & & 87 & & & 5 & & & & & & & & & \\
\hline & 11 & $120-130$ & 303 & & & & & & 4 & 1 & & & & & & & & \\
\hline & 12 & $130-140$ & 21 & & & & & & & & & & & & & & & \\
\hline & 13 & $140-150$ & 16 & & & & & & & & & & & & & & & \\
\hline & 14 & $150-160$ & 19 & & & & & & & & & & & & & & & \\
\hline & 15 & $160-170$ & & & & & & & & & & & & & & & & \\
\hline & 16 & $170-180$ & 4 & & & & & & & & & & & & & & & \\
\hline & 17 & $180-190$ & & & & & & & & & & & & & & & & \\
\hline & 18 & $190-200$ & & & & & & & & & & & & & & & & \\
\hline \multirow{9}{*}{$\begin{array}{l}\text { जี } \\
\tilde{\infty}\end{array}$} & 1 & $0-30$ & & & & & & & & & & & & & & & & \\
\hline & 2 & $30-40$ & & & & & & & & & & & & & & & & \\
\hline & 3 & $40-50$ & 98 & & & & & & & & & & & & & & & \\
\hline & 4 & $50-60$ & 115 & & & & & & & & & 1 & & & & & & \\
\hline & 5 & $60-70$ & 159 & & & & & & & & & & & & & & & \\
\hline & 6 & $70-80$ & 285 & 6 & 1 & & & & & & & & & & & & & \\
\hline & 7 & $80-90$ & 313 & 2 & & & & & & & & & & & & & & \\
\hline & 8 & $90-100$ & 529 & & & & & & & & & & & & & & & \\
\hline & 9 & $100-110$ & 252 & & & & & & & & & & & & & & & \\
\hline \multirow{9}{*}{$\begin{array}{l}\vec{n} \\
\tilde{m}\end{array}$} & 1 & $0-30$ & 6 & & & & & & & & & & & & & & & \\
\hline & 2 & $30-40$ & 188 & & & & & & & & 1 & & & & & & & \\
\hline & 3 & $40-50$ & 332 & & & & 1 & & & & & & & & & & & \\
\hline & 4 & $50-60$ & 98 & & & & & & & & & & & & & & & \\
\hline & 5 & $60-70$ & 262 & & & & & & & & & & & & & & & \\
\hline & 6 & $70-80$ & 331 & 3 & 1 & 254 & & & & & & & & & & & & \\
\hline & 7 & $80-90$ & 399 & 4 & & & & & & & & & & & & & & \\
\hline & 8 & $90-100$ & 625 & 1 & & & & & & & & & & & & & & \\
\hline & 9 & $100-110$ & 210 & & & & & & & & & & & & & & & \\
\hline \multirow{14}{*}{$\begin{array}{l}\text { Nิ } \\
-1\end{array}$} & 1 & 0-30 & 21 & & & & & & & & & & & & & & & \\
\hline & 2 & $30-40$ & 129 & & & & & & & & & & & & & & & \\
\hline & 3 & $40-50$ & 276 & & & & & & 1 & & & & & & & & & \\
\hline & 4 & $50-60$ & 245 & 1 & & & & & & & & & & & & & & \\
\hline & 5 & $60-70$ & 345 & & & & & & & & & & & & & & & \\
\hline & 6 & $70-80$ & 762 & 2 & & & & & & & & & & 1 & & & & \\
\hline & 7 & $80-90$ & 1,539 & & & & 1 & & & & & & & 1 & & & & \\
\hline & 8 & $90-100$ & 771 & 2 & & & & & & & & & & & & & & \\
\hline & 9 & $100-110$ & 443 & & & & & & 1 & & & & 1 & & & & & \\
\hline & 10 & $110-120$ & 645 & & & & & 1 & & & & & 1 & 1 & & & & \\
\hline & 11 & $120-130$ & 308 & & & & & & & & & & & & & & 1 & \\
\hline & 12 & $130-140$ & 224 & & & & & & & & & & & & 1 & & & \\
\hline & 13 & $140-150$ & 95 & & & & & & & & & & & 1 & & & & \\
\hline & 14 & $150-160$ & 2 & & & & & & & & & & & & & & 1 & \\
\hline
\end{tabular}




\begin{tabular}{|c|c|c|c|c|c|c|c|c|c|c|c|c|c|c|c|c|c|c|}
\hline 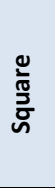 & 䓂 & 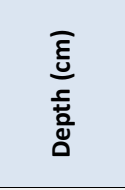 & 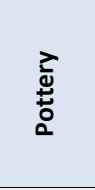 & 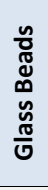 & 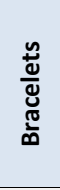 & 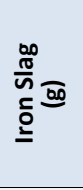 & $\begin{array}{l}\text { एँ } \\
\sum\end{array}$ & 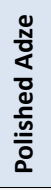 & 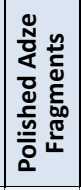 & 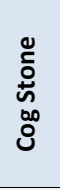 & 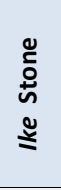 & 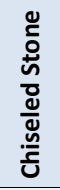 & 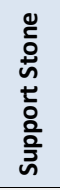 & 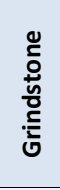 & 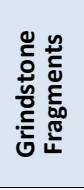 & 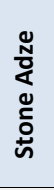 & $\frac{\tilde{\mathscr{U}}}{\frac{\pi}{\frac{\pi}{L}}}$ & 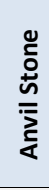 \\
\hline \multirow{14}{*}{$\begin{array}{l}n \\
\sim \\
\dot{\infty}\end{array}$} & 1 & $0-30$ & 7 & & & & & & & & & & & & & & & \\
\hline & 2 & $30-40$ & 113 & & & & & & & & & & & & & & & \\
\hline & 3 & $40-50$ & 79 & & & & & & & & & & & & & & & \\
\hline & 4 & $50-60$ & 52 & & & & & & & & & & & & & & & \\
\hline & 5 & $60-70$ & 185 & & & & 1 & & & & & & & & & & & \\
\hline & 6 & $70-80$ & 637 & & & 9 & 1 & & & & & & & & & & & \\
\hline & 7 & $80-90$ & 870 & & & & & & & & & & 1 & & & & & \\
\hline & 8 & $90-100$ & 540 & & & & & & & & & & & 1 & & & & \\
\hline & 9 & $100-110$ & 290 & & & & & & & & & & & & & & & \\
\hline & 10 & $110-120$ & 1,005 & 1 & & & & 1 & 4 & & & & 5 & & & 1 & & \\
\hline & 11 & $120-130$ & 373 & & & & & & & & & & & & & & & \\
\hline & 12 & $130-140$ & 99 & & & & & & & & & & & & & & & \\
\hline & 13 & $140-150$ & 4 & & & & & & & & & & & & & & & \\
\hline & 14 & $150-160$ & 5 & & & & & & & & & & & & & & & \\
\hline \multirow{13}{*}{$\begin{array}{l}\stackrel{m}{\mathscr{U}} \\
\stackrel{\infty}{\leftarrow}\end{array}$} & 1 & $0-30$ & & & & & & & & & & & & & & & & \\
\hline & 2 & $30-40$ & 16 & & & & & & & & & & & & & & & \\
\hline & 3 & $40-50$ & 104 & & & 21 & & & & & & & & & & & & \\
\hline & 4 & $50-60$ & 85 & & & 226 & & & & & & & & & & & & \\
\hline & 5 & $60-70$ & 13 & & & & & & & & & & & & & & & \\
\hline & 6 & $70-80$ & 342 & 1 & & & & & & & & & & & & & & \\
\hline & 7 & $80-90$ & 1,323 & 1 & & & & & & & & & 2 & & & & & \\
\hline & 8 & $90-100$ & 1,474 & 1 & & & & & 3 & & & & 1 & & & & & 1 \\
\hline & 9 & $100-110$ & 356 & 1 & & & & 1 & & & & & 1 & & & & & \\
\hline & 10 & $110-120$ & 246 & & & & & & 2 & & & & & & & & 1 & \\
\hline & 11 & $120-130$ & 91 & & & & & & & & & & & & & & & \\
\hline & 12 & $130-140$ & 59 & & & & & & & & & & & & & & & \\
\hline & 13 & $140-150$ & & & & & & & & & & & & & & & & \\
\hline \multirow{10}{*}{$\vec{r}$} & 1 & $0-30$ & & & & & & & & & & & & & & & & \\
\hline & 2 & $30-40$ & 3 & & & & & & & & & & & & & & & \\
\hline & 3 & $40-50$ & 29 & & & & & & & & & & & & & & & \\
\hline & 4 & $50-60$ & 7 & & & & & & & & & & & & & & & \\
\hline & 5 & $60-70$ & 509 & & & 22 & & & & & 1 & & & & & & & 1 \\
\hline & 6 & $70-80$ & 1,907 & 1 & & 63 & & & & & & & & 1 & & & & \\
\hline & 7 & $80-90$ & 579 & 1 & & & & 1 & & & & & & & & & & 2 \\
\hline & 8 & $90-100$ & 174 & & & & & & & & & & & & & & & \\
\hline & 9 & $100-110$ & 39 & & & & & & 1 & & & & & 1 & & & & \\
\hline & 10 & $110-120$ & 18 & & & & & & & & & & & & & & & \\
\hline \multirow{10}{*}{$\begin{array}{l}N \\
\stackrel{R}{1}\end{array}$} & 1 & $0-30$ & & & & & & & & & & & & & & & & \\
\hline & 2 & $30-40$ & & & & & & & & & & & & & & & & \\
\hline & 3 & $40-50$ & & & & & & & & & & & & & & & & \\
\hline & 4 & $50-60$ & 6 & & & & & & & & & & & & & & & \\
\hline & 5 & $60-70$ & 238 & & & & & & & & & & & & & & & \\
\hline & 6 & $70-80$ & 376 & & & & & & & & & & & & & & & \\
\hline & 7 & $80-90$ & 167 & & & & & & & & & & & & & & & \\
\hline & 8 & $90-100$ & 85 & & & & & & & & & & & & & & & \\
\hline & 9 & $100-110$ & 23 & & & & & & & & & & & & & & & \\
\hline & 10 & $110-120$ & & & & & & & & & & & & & & & & \\
\hline \multicolumn{3}{|c|}{ Total } & 26,860 & 35 & 3 & 1,311 & 4 & 4 & 21 & 1 & 2 & 1 & 12 & 7 & 1 & 1 & 3 & 4 \\
\hline
\end{tabular}

Source: Balai Arkeologi Sulawesi Selatan, 2014, 2016, 2017, Fakhri et al., 2015

\section{CONCLUSION}

The conclusion based on the research result is show there is an indication of older occupation (Neolithic phase), before entering the early metal phase stage at Sakkarra. However, this period does not last long, before finally entering the stage of intensive occupancy by 2,000 years ago. Neolithic cultural traditions have not disappeared and still inherent in their cultural order when metal knowledge begins to present in Karama Drainage. Cultural continuity is reflected in the maintenance of Neolithic technological traditions such as the manufacture of earthenware pottery and polished stone tools. On the other hand, the appearance of glass and iron artifacts heralds the introduction of new cultural influences on the Karama drainage inhabitants. Certainly, the polished cog stone is difficult to ascribe to external 
influence because examples of this tool type do not appear to have been documented from other sites. Thus, the example of Sakkarra suggests that the Neolithic to Metal Phase transition involved continuity of Neolithic technology but with scope for local innovation, along with the capacity to absorb metallurgy and participate in the growing trade in glass and other exotic items. The cultural layer in Sakkara Site indicates the existence of Austronesian speakers' occupation that continues from the Neolithic phase to the initial metal phase in Karama Drainage. Even they are actively involved in the shipping and trade that had intertwined among the islands in Southeast Asia at that time.

\section{ACKNOWLEDGEMENT}

The research funds in this paper come from the annual fund research program of Balai Arkeologi Sulawesi Selatan in 2014, 2016, and 2017 along with funding from The Anthony F. Granucci Fund in 2014. Therefore, many thanks to Head of Pusat Penelitian Arkeologi Nasional and Head of Balai Arkeologi Sulawesi Selatan. Thanks to Prof. Peter Bellwood and Dr. David Bulbeck for the discussion and guidance during the research process on Sakkarra. Moreover, thanks to Ratno Sardi, Arizal Purnama, Asrianti, Andika Saputra, Erlan Djulani, Wiwin, and Adhe Syarafat who have contributed during the research.

$* * * * *$

\section{REFERENCES}

Anggraeni. (2012). The Austronesian Migration Hypothesis as Seen from Prehistoric Settlements on the Karama River, Mamuju, West Sulawesi. The Australian National University.

Anggraeni, Simanjuntak, T., Bellwood, P., \& Piper, P. (2014). Neolithic Foundations in the Karama Valley, West Sulawesi, Indonesia. Antiquity, 88(341), 740-756.

Bellwood, P. (2007). Prehistory of the Indo-Malaysian Archipelago. Sydney: ANU E Press.

Fakhri, Suryatman, Hakim, B., \& Sardi, R. (2015). Exploration of Prehistoric Sites in the Karama Watershed, West Sulawesi, Indonesia: from early occupation until the metal age. Journal of Indo-Pasific Archeology, 39, 1824.

Hakim, B. (2014). Archaeological Traces of Austronesian Ancestors at the Kamansi Site of the Karama River Valley in West Sulawesi, Indonesia. Journal of Austronesian Studies, 5(1), 73-95.

Hakim, B., Fakhri, Suryatman, Saiful, A. M., Kurata, Y., Purnama, D., ... Hasrianti. (2014). Laporan Penelitian: Sejarah Hunian Awal Penutur Austronesia di Daerah Aliran Sungai Karama, Kabupaten Mamuju, Sulawesi Barat. Makassar: Balai Arkeologi Makassar.
Hakim, B., Suryatman, Fakhri, Sardi, R., Hasliana, Purnama, D., ... Hamzah, H. (2017). Laporan Penelitian Ekskavasi Tahap III Situs Sakkarra di DAS Karama, Kabupaten Mamuju: Hunian Budaya Prasejarah Austronesia Fase Logam. Makassar: Balai Arkeologi Sulawesi Selatan.

Hakim, B., Suryatman, Sardi, R., Purnama, D., Kurata, Y., Hamzah, M., ... Hasriani, A. (2016). Laporan Penelitian Ekskavasi Tahap II Situs Sakkarra, di DAS Karama, Kabupaten Maтuju. Makassar: Balai Arkeologi Makassar

Morwood, M. J., Mahmud, M. I., \& Simanjuntak, T. (2007). Penelitian Situs Minanga Sipakko dan Sekitarnya. In T. Simanjuntak, M. F. S. Intan, \& M. I. Mahmud (Eds.), Kalumpang: Arkeologi dan Etnografi (pp. 46-53). Jakarta: Pusat Penelitian dan Pengembangan Arkeologi Nasional.

Nasruddin. (2016). Artefak Manik-manik dalam Perspektif Arkeologi. Jurnal Papua, 8(1), 81-94.

Reepmeyer, C., Spriggs, M., Anggraeni, Lape, P., Leee Neri, Ronquillo, W. P., ... Tiauzon, A. (2011). Obsidian sources and distribution system in Island Southeast Asia: new results and implications from geochemical research using LA-ICPMS. Journal of Archaeological Science, 38(11), 2995-3005.

Simanjuntak, T. (1994). Kalumpang: Hunian Tepi Sungai Bercorak Neolitik-Paleometalik di Pedalaman Sulawesi Selatan. In Aspek-aspek Arkeologi Indonesia No. 17. Jakarta: Pusat Penelitian dan Pengembangan Arkeologi Nasional.

Simanjuntak, T. (2015). Progres Penelitian Austronesia di Nusantara. Amerta, 33(1), 25-44.

Simanjuntak, T., Intan, M. F. S., \& Mahmud, M. I. (2007). Kalumpang: Arkeologi dan Etnografi. Jakarta: Pusat Penelitian dan Pengembangan Arkeologi Nasional.

Simanjuntak, T., Morwood, M. J., Intan, M. F. S., Mahmud, M. I., Grant, K., Somba, N., ... Utomo, D. W. (2008). Minangasipakko and Neolithic of the Karama River. In T. Simanjuntak (Ed.), Austronesian in Sulawesi (pp. 5776). Center for Prehistoric and Austronesian Studies.

Simanjuntak, T., Oktaviana, A. A., \& Handini, R. (2016). Updated Views on the Austronesian studies in Indonesia. In B. Prasetyo, T. S. Nastiti, \& T. Simanjuntak (Eds.), Austronesian diaspora: A new Perspective (pp. 207-222). Yogyakarta: Gadjah Mada University Press.

Spriggs, M., Reepmeyer, C., Lape, P., Neri, L., Ronquillo, W. P., Simanjuntak, T., ... Tiauzon, A. (2011). Obsidian Sources and Distribution Systems in Island Southeast Asia: a review of previous research. Journal of Archaeological Science, 38(11), 2873-2881.

Suryatman, Hakim, B., \& Fakhri. (2016). The Sakkarra site: New data on prehistoric occupation from the Metal Phase (2000 BP) along the Karama drainage, West Sulawesi. In The archaeology of Sulawesi - an update. Makassar: The Australian National University.

Suryatman, Hakim, B., \& Fakhri. (2018). The Sakkarra site: New data on prehistoric occupation from the Metal Phase (2000 BP) along the Karama drainage, West Sulawesi. In S. O'Connor, D. Bulbeck, \& J. Meyer (Eds.), terra australis 48 The Archaeology of Sulawesi Current Research on the Pleistocene to the Historic Period (pp. 207-221). Acton: ANU Press.

Yuniawati, D. Y. (2014). Laporan Penelitian Arkeologi potensi peradaban budaya megalitik di Lembah Rampi, Kabupaten Luwu Utara, Provinsi Sulawesi Selatan. Jakarta. 